\title{
Leaderless Country: A Study of Pakistan
}

\author{
Khalid Mehtabdin \\ The College of Saint Rose, Albany, USA
}

\begin{abstract}
Pakistan is a country built on the foundation of Islam and religious freedom. The purpose of this paper is to discuss why, though, it is not yet a unified nation despite its annexation from India in 1947. Also, the purpose of this paper is to bring up and answer several other questions regarding Pakistan, including: the Kashmir issue, water shortage, general malaise of the economy, and overall sectarian conflicts, along with terrorism, and also how to attract foreign investment. Without a strong infrastructure in place, Pakistan has struggled to gain the foreign investment required of a struggling economy to grow. The political and religious factions of this country have yet to find a way to work together to unite its people. The general poverty and lack of education in Pakistan has limited its people's opportunities to productively contribute to the global economy, and has allowed religious extremists to gain a foothold. The violence and terror that has occurred has further limited foreign interest in investing in such a volatile country. All of these factors contribute to the need for a strong leader in Pakistan if there is to be any progress made in the coming years. Leaders inspire people, but ever since the partition days, no leader has been able to move the country forward. There's an urgent need, now, for someone who would advance the national interests rather than personal interests. This paper deals with the issues raised above, and suggests some possible answers dealing with the situation. For Pakistan to become a nation, it has to unite its people, which has been lacking all along. Most of the analysis is descriptive, because most of the data are not representative of the real situation of the inequities which are prevailing among the various provinces of Pakistan. The issue of Kashmir has been lingering on since the partition days, and no leader has been courageous enough to handle it up front.
\end{abstract}

Keywords: leaderless, Pakistan, country analysis, economic problems, macro issues, recommendations for improvement

\section{Introduction and History}

The importance of this study is to highlight the past trends and present problems facing Pakistan. No proper solutions have been fully identified, in the past, to highlight what Pakistan will be facing in the near future, which this paper attempts to address.

To understand the systemic issues of Pakistan, it is important to first understand its rich history. The plot of fertile land that is today's Pakistan was once ruled by several ancient cultures throughout its past such as the Mehrgarh of the Neolithic and the Bronze Age Indus Valley Civilization (Bates, 2011, BBC). Pakistan has been

Acknowledgments: Ameer Poonawala for assembling all the material for the author. He played an important part in finalizing and assembling this paper under the author's guidance. Mr. Andrew Kochian was instrumental in formatting this paper for publication purposes.

Khalid Mehtabdin, Ph.D., professor of economics, School of Business, The College of Saint Rose, Albany, NY, USA.

Correspondence concerning this article should be addressed to Khalid Mehtabdin, The College of Saint Ros, 432 Western Avenue, Albany, NY 12203, USA. 
home to a variety of religious faiths and cultures including Hindus, Muslims, Afghans, Indo-Greeks, Turco-Mongols, and Sikhs. These religious influences shaped Pakistan, but it is a predominantly Muslim country today.

According to the Pakistan government's official chronology, Arab conqueror Muhammed bin Qasim taking over much of the Indus valley was the point where the foundation of Pakistan began (Bates, 2011, BBC). Increased European influence by the early 18th century really changed the outlook of Pakistan. By this time, the English East India Company had many coastal outposts. The East India Company had the ability to flex their military muscle by this time, and they used that advantage to take most of the subcontinent from the rest of Europe by 1765 (Bates, 2011, BBC). By the 1820's, they had subdued or annexed most of the region. Through various limitations by the British Parliament, the East India Company lost many of its economic power. They were eventually viewed as an extension of the British government, and it is commonly believed that this was the beginning of the colonial period for Pakistan.

There was a great deal of religious conflict between the Hindus and Muslims in the Indian colony, which led to the interest in creating a separate Muslim state. The power struggle between the Muslim League and Congress forced the hand of the British to speed up the independence movement. Rioting occurred all over the land in the 1940's, with the massacre of Muslims in Calcutta bringing Gandhi to the scene (BBC). This may have helped both sides realize that nobody would win this potential civil war if concessions weren't made. After gaining its freedom, India and Pakistan partitioned the land in an attempt to give followers of both religions a place to call home.

The India Independence Act was passed on July 14, 1947 (Bates, 2011, BBC). This created two independent dominions on the subcontinent, with the princely states in between being allowed to choose which side they went to. Most of these states chose quickly, but Kashmir and Jammu proved to be a bigger problem. This leads to one of the major issues of today: the struggle between Pakistan and India for control of Kashmir. It has led to multiple wars and conflicts between the two nations and may never get resolved. While Pakistan gained its independence from the British Empire as well as India, it was not a bloodless struggle. The tumultuous past of Pakistan allows one to understand where many of its current issues arise.

\section{Problems Facing Pakistan \& Possible Solutions}

\section{Education}

Only $87 \%$ of Pakistani children finish primary school education. The standard national system of education is mainly inspired from the British system. Pre-school education is designed for three to five years old and usually consists of three stages: Play Group, Nursery, and Kindergarten. After pre-school education, students go through junior school from grades 1 to 5 . This is proceeded by middle school from grades 6 to 8 . At middle school, single-sex education is usually preferred by the community, but co-education is also common in urban cities. The curriculum is usually subject to the institution. The eight commonly examined disciplines are Urdu, English, mathematics, arts, science, social studies, Islamic studies, and sometimes computer studies. Literacy rates have improved slightly but Pakistan has not been able to meet its medium term target and will most likely miss the Millenium Development Goal as well (Ali, 2013, Education.in.Pakistan).

Free and compulsory basic education is a fundamental right of every human being as guaranteed by the Universal Declaration of Human Rights and the Constitution of Pakistan (Ali, 2013, Education.in.Pakistan). 
Despite the obvious benefits of educating one's citizens, it has always taken a back seat when it comes to budgetary allocation and ensuring effective utilization of resources in Pakistan. According to the UNESCO National Final Report Education Analysis, Pakistan was expected to increase their education expenditure by $0.2 \%$ every year starting in 2004. When looking at the numbers, it shows that they have not been able to keep up with this goal since 2005. Their expenditure actually decreases during some years, with the worst drop off being in 2009 to 2010. This drop off was from $2.05 \%$ to $1.4 \%$, well below the $3.4 \%$ that was their goal. The 18th Amendment led to provinces being much more responsible for education costs, and this has allowed the federal government to limit its allocation to this sector.

The fact that Pakistan has put the majority of education expenses and duties on the provinces is a very risky move. While the federal government may not have the funds to cover education, it is alarming that they expect the individual provinces to come up with the money required. Combined with the lack of infrastructure that will be discussed later in this paper, it is a recipe for disaster in the long run. It is fairly common knowledge in the economic and social development community that increasing the quality of education is the quickest way to see positive changes in a country's GDP. Some would say that this similar disregard for education in the federal budget is hurting America in the same way. There is no way to avoid investing large amounts of your budget into the military and security in areas such as the Middle East, but there needs to be a better balance from the Pakistani government moving forward. The fact that they are not hitting their modest goal of $0.2 \%$ increase in expenditure is very alarming.

\section{The Situation in Kashmir}

The Kashmir conflict is a major territorial dispute between India and Pakistan that dates back prior to independence. While regular peace talks have occurred since 2010, a diplomatic solution has not been reached. India and Pakistan have fought three wars over Kashmir, including the Indo-Pakistani Wars of 1947, 1965, and 1999. Furthermore, since 1984 the two countries have also been involved in several skirmishes over control of the Siachen Glacier. India claims the entire state of Jammu and Kashmir and as of 2010, administers approximately $43 \%$ of the region, including most of Jammu, the Kashmir Valley, Ladakh, and the Siachen Glacier. India's claims are contested by Pakistan, which administers approximately 37\% of Kashmir, namely Azad Kashmir and the northern areas of Gilgit Baltistan (Sabih, 2015, Al Jazeera).

The roots of the conflict between the Kashmiri insurgents and the Indian Government are tied to a dispute over local autonomy. Democratic development was limited in Kashmir until the late 1970s and by 1988 many of the democratic reforms provided by the Indian Government had been reversed. Non-violent channels for expressing discontent were thereafter limited and caused a dramatic increase in support for insurgents advocating violent secession from India. In 1987, a disputed state election created a catalyst for the insurgency when it resulted in some of the state's legislative assembly members forming armed insurgent groups. In July 1988 a series of demonstrations, strikes, and attacks on the Indian Government began the Kashmir Insurgency.

According to the Indian Independence Act 1947, "the sovereignty of His Majesty over the Indian States lapses and with it, all treaties and agreements in force at the date of the passing of this Act between His Majesty and the rulers of Indian States”. States were thereafter left to choose whether to join India or Pakistan or to remain independent. Jammu and Kashmir, the largest of the princely states, had a predominante Muslim population ruled by the Hindu Maharaja Hari Singh. Following partition, Pakistan had expected the annexation of Kashmir to its territory. 
Hari Singh, the maharaja of Kashmir, initially believed that by delaying his decision he could maintain the independence of Kashmir, but, caught up in a train of events that included a revolution among his Muslim subjects along the western borders of the state and the intervention of Pashtun tribesmen, he signed an instrument of accession on 25 October 1947 to the Indian union. This was the signal for intervention both by Pakistan, which considered the state to be a natural extension of Pakistan, and by India, which intended to confirm the act of accession.

This struggle between India and Pakistan over the ownership of Kashmir has been a huge thorn in the side of both countries. The thousands of lives that have been lost over this debate are just one of the problems associated with it. It seems as though neither country will ever admit defeat in this regard, funneling highly valuable resources to the border debate. As this paper will make evident, Pakistan does not have the economic ability to fight this pointless battle. It is in their best interest to come to some form of agreement with India so that they can focus on the issues keeping it from prospering.

\section{Water Shortage}

It's been predicted that by 2025, Pakistan will be facing very severe shortage of clean water; it is well known that most of the water comes from the Himalayas, and that area is being controlled by India. If the Kashmir issue is not resolved within the next few years, Pakistan may end up facing not only a severe shortage of water, but also a famine, which has already been talked about.

\section{Religious Extremism}

Religion has been the trigger for conflict in Pakistan since before it gained independence. With half of Pakistan's population being illiterate and upwards of 24 percent living below the poverty line, it is quite safe to say that they are easy targets for religious extremists (Khan, 2016, Digital Development). Pakistan is also expected to surpass Indonesia as the country with the largest Muslim population by 2030 (Khan, 2016, Digital Development). These factors contribute to the high rate of terrorism in the country.

Terrorism in Pakistan has become a major and highly destructive phenomenon in recent years. The annual death toll from terrorist attacks has risen from 164 in 2003 to 3,318 in 2009 with a total of 35,000 Pakistanis killed between September 11, 2001 and May 2011 (Institute for Conflict Management, 2012, SATP). According to the government of Pakistan, the direct and indirect economic costs of terrorism from 2000-2010 are total \$68 billion. President Asif Ali Zardari, along with former President ex-Pakistan Army head Pervez Musharraf, has admitted that terrorist outfits were "deliberately created and nurtured” by past governments "as a policy to achieve some short-term tactical objectives". The trend began with Muhammad Zia-ul-Haq's controversial "Islamization" policies of the 1980s, under which conflicts were started against Soviet involvement in Afghanistan (Institute for Conflict Management, SATP). Zia's tenure as president saw Pakistan's involvement in the Soviet-Afghan War, which led to a greater influx of ideologically driven Muslims to the tribal areas and increased availability of guns such as the AK-47 and drugs from the Golden Crescent (Khan, 2016, Digital Development).

From the summer of 2007 until late 2009, more than 1,500 people were killed in suicide and other attacks on civilians for reasons attributed to a number of causes—sectarian violence between Sunni and Shia Muslims; easy availability of guns and explosives; the existence of a "Kalashnikov culture"; an influx of ideologically driven Muslims based in or near Pakistan, who originated from various nations around the world and the subsequent war against the pro-Soviet Afghans in the 1980s which blew back into Pakistan; the presence of 
Islamist insurgent groups and forces such as the Taliban and Lashkar-e-Taiba; Pakistan's thousands of fundamentalist madrassas which are thought by many to provide training for little other than jihad and secessionists movements - blamed on regionalism, which is problematic in a country with Pakistan's diverse cultures, languages, traditions, and customs (Digital Daily).

Since 2001 religious extremism has overtaken national separatism to become the main driver of terrorist attacks around the world, according to the Global Terrorism Index. Somebody can do very extreme things if they feel their violent acts are what their religion wants of them. When a powerful general convinces children to strap bombs to their chests, it is by giving them the belief their family will be taken care of and they will be rewarded in the afterlife. The sheer volume of illiterate and impoverished in their community will lead to enough volunteers to keep the violence going.

\section{Peshawar Public School Shooting}

One of the greatest tragedies in Pakistan in recent memory is the attack on the school in Peshawar in December of 2014. The Taliban had nine gunmen shoot up the school and killed one hundred and forty one people. Of these deaths, one hundred and thirty two were children attending classes that day. The Taliban chose to single out the army run school in the deadliest terror attack in Pakistani history. Peshawar is located in the northwest region of Pakistan, and this is where the Taliban took their war on education.

During an eight-hour attack, the nine gunmen stormed through the corridors and assembly hall of the Army Public School and Degree College. They fired at random and threw grenades at the 1,100 students in the school. Some of the students were lined up and executed, while others were shot as they ran from the attackers. These gunmen even forced children to watch as they riddled their teachers with bullets. Parents waited outside as they prayed for their children to be safe, but many parents were not so lucky.

These gunmen were able to sneak into the school with paramilitary disguises. Once the attacks began, Pakistan's elite Special Services group moved in. This led to a firefight between the military and Taliban gunmen, with shots being fired throughout the school. Survivors reported that some attackers were speaking in Arabic, while others were speaking in Pashto (Walsh, 2014, NY Times). The siege capped a very violent year for Pakistan. The polio virus has spread from the tribal belt to Karachi, aided by militant attacks on health workers giving vaccines (Walsh, 2014, NY Times). Political feuding has brought the government and the major cities to a standstill.

A Taliban spokesman said the attack had been motivated by an attempt for retaliation. The Taliban have been fighting with the military in the North Waziristan region, and this was supposed to be their response to the continued military presence (Walsh, 2014, NY Times). Many of the students at this school were sons and daughters of army personnel. This attack has garnered national attention for obvious reasons, leaving many people outraged over the tragedy. Even the Afghanistan Taliban issued a statement via Twitter saying the attacks were un-Islamic (Walsh, 2014, NY Times). This is interesting considering the high death tolls that the Taliban in Afghanistan are responsible for. This outrage expressed could be due to the fact that there are many different factions within the various Taliban organizations throughout the Middle East. Claiming moral high ground is difficult to do for the Afghanistan Taliban, but they found an opportunity to criticize and took it. This tragedy is another example that most of these terrorist attacks are aimed at people who are too weak to do anything about it. 
On December 17 2014, Prime Minister Nawaz Sharif approved paperwork to remove the moratorium on the death penalty in terror-related cases (Walsh, 2014, NY Times). Sources from the Prime Minister's Secretariat stated: "The Prime Minister has approved abolishment of moratorium on the execution of death penalty in terrorism-related cases.” Pakistan has had a moratorium on executions since 2008. Currently there are approximately 800 people on death row in Pakistan in terrorism related cases. The move comes following the widely held perception that terrorists are never brought to justice in Pakistan. Many times, the judges and witnesses are too scared to come forward and award due sentences to the terrorists. And even when the terrorists are convicted and sent to prison, the frail policing system of Pakistan has seen many jailbreaks, including the Bannu and Dera Ismail Khan jailbreaks, in which many high-profile terrorists escaped (Walsh, 2014, NY Times).

Also on December 17, Pakistan's former Chief of Army Staff General Raheel Sharif, accompanied by the Director General of the Inter-Services Intelligence, Lieutenant-General Rizwan Akhtar, went to Kabul to meet with Afghan President Ashraf Ghani and General John F. Campbell, the Commander of American and NATO forces in Afghanistan. According to news sources in Pakistan, General Raheel asked for the handover of the TTP leadership and asked the Afghan government to act against hideouts of the Taliban terrorists in its territory. At the meeting with Afghan officials, General Raheel delivered a message to Afghan National Army's Chief of Staff, Lieutenant General Sher Mohammad Karimi, "to take decisive action against sanctuaries of the TTP or else Pakistan would go for a hot pursuit” (Walsh, 2014, NY Times). One intelligence official confirmed the message relayed to the Afghan president and reportedly cautioned that "if Afghan authorities fail to act this time, we will explore all options, including hot pursuit.” In further talks, General Raheel told the Afghan president that "Pakistan's military could eliminate TTP's sanctuaries in Kunar and Nuristan Province on its own but was showing restraint due to Afghanistan's sovereignty and territorial integrity”. President Ghani assured General Raheel that his country would take all the necessary steps to root out the terrorists (Sabih, 2015, Al Jazeera).

All of this talk is great, but it will require a huge stray in public policy from the past. Repealing the ban on the death penalty for terrorists is the first step, but many of these terrorists aren't afraid of death. The attack in Peshawar can be thought of as a scare tactic by the Taliban, attempting to remind the citizens that they are not safe anywhere. It can also be seen as a way to show the citizens that they can't be protected properly by their army or their government, so they should choose wisely which side they are on.

\section{Foreign Influences}

Pakistan has always had a very strong bilateral relationship with Saudi Arabia. These two countries have chosen to help each other due in large part to their Islamic ties. Since the establishment of Pakistan in 1947, these two countries have sought to work together to develop extensive cultural, economic, political, and strategic relations. Pakistan even affirms this relationship by listing Saudi Arabia as the most important and bilateral partnership in their foreign policy. According to a recent Pew Research center survey, 95\% of Pakistanis view Saudi Arabia in a positive light (Rafiq, 2015, Foreignpolicy.com). The former Saudi intelligence chief Prince Turki bin Faisal once described ties between Pakistan and Saudi Arabia as "probably one of the closest relationships in the world between any two countries without any official treaty”.

Pakistan and Saudi Arabia have such a strong relationship due to the ability of each country to provide something useful for each other that they could not manage alone. In the case of Pakistan, it has one of the 
largest militaries in the world. This is particularly useful to Saudi Arabia, as they have plenty of enemies that would think twice before attacking. Pakistan also has nuclear weapons, something that no other Islamic state can boast of. Saudi Arabia is rumored to have donated oil supplies to Pakistan in 1998 when they were hit with sanctions for conducting nuclear tests (SOURCE). In 1969, Pakistani pilots flew Saudi jets to thwart Yemeni incursions into the kingdom. Islamabad and Riyadh closely coordinated support for the mujahedeen in the war against the Soviet occupation of Afghanistan in the 1980s; and during that decade, Pakistan stationed upwards of 15,000 troops in Saudi Arabia. Pakistani troops returned to Saudi Arabia during the first Gulf War to protect it from an Iraqi invasion (SOURCE). Saudi Arabia has a very strong economy due to their vast oil reserves. This gives them the ability to offer financial gains to Pakistan for their protection.

The problem with this relationship is that it is difficult to tell if both sides are benefitting equally from it. While both countries may share an ideology, there are many other factors at work in the Middle East. With constant conflict between these countries, it isn't plausible for Pakistan to risk entering wars without a very good reason. Despite this, the financial incentive to help Saudi Arabia can be difficult for Pakistan to ignore, especially given the state of its own economy. In 2014, Pakistan was given a 1.5 billion dollar "gift" from Riyadh after they changed their stance on Syrian involvement (SOURCE). Even though the claim is that the gift was given with no strings attached, there is clear evidence that the Saudis will try pulling the strings of Pakistan using their wallets.

In recent years, Islamabad has balked at Saudi requests for assistance, including for the deployment of 15,000 Pakistani troops to the kingdom in 2014. This is in part because roughly 30 percent of Pakistan's active-duty troops have been deployed in the country's northwest since 2009 fighting against the Taliban insurgency. Troop levels along the Afghanistan border will remain constant until 2019, leaving Pakistan with a reduced presence along its tense eastern border with India and few troops to spare for anywhere else (Rafiq, 2015, Foreignpolicy.com).

Pakistan and the United States of America have a long history of cooperation and conflict. Despite their differences in ideology, these two countries have found reasons to assist one another numerous times since Pakistan became a sovereign country. From the Cold War to the more recent troubles in Afghanistan, these two countries have worked together when their causes were joined. Both countries have strong military presence and nuclear weapons, although it is no secret that the United States is significantly stronger than Pakistan and can use this political and military strength to bend the will of Pakistan.

While the people of Pakistan have an overwhelmingly positive view on Saudi Arabia, the same cannot be said about their view of Americans. A recent Pew Research Center Global Attitudes poll found that only 38\% of Pakistanis have a favorable view of America, starkly different than the 95\% who view Saudi Arabia positively (Rafiq, 2015, Foreignpolicy.com). The reasons for this are quite clear, with most of the Middle East having this negative view on Americans as a self-entitled and lazy society. The United States constant conflicts with various Islamic factions and terrorist groups are another reason for this outlook.

Interestingly enough, that same poll found that only $18 \%$ of Americans had a favorable view of their frontline allies in Pakistan. This indicates that both countries have a very suspicious attitude towards each other. The governments of these countries don't help foster a sense of security either. Relations began to strain as both sides began to criticize one another's strategy in the War on Terror, with the United States government frequently accusing Pakistan of harboring members of the Afghan Taliban and Quetta Shura, while Pakistan 
has alleged that the United States has done little to control security in the area (Rumi, 2015, Foreignpolicy.com).

The relations between Pakistan and their two foreign allies certainly have their differences, but there is a similarity in that Pakistan is the country with the least power in each relationship. It can be said that if Pakistan wasn't located so centrally in the conflict in the Middle East, neither Saudi Arabia nor the United States would help them at all. They would be left to fend for themselves like most of the other countries in the area. Pakistan lacks the economic strength of Saudi Arabia or America, so they are often left to do their dirty work in order to get paid.

\section{Infrastructure}

For a country to truly thrive, they need a strong infrastructure in place. This infrastructure allows them to efficiently travel and transport items throughout the country. Studying a country's infrastructure can give strong indicators as to which direction the economy is heading in. When a country has a strong infrastructure, it gives confidence for others to invest in them. When looking at the infrastructure of Pakistan, it is clear that there are many issues at play here. These contribute to the lack of foreign investment in Pakistan in any of the higher paying sectors. While there is no shortage of factories and sweat shops in Pakistan, the way to move forward as a country is to provide resources for the technological and energy sectors.

When looking at the infrastructure of Pakistan, it is clear that there are issues. The domestic transportation system was not well developed at independence. At that time, railroads were the most common form of transportation (Globalsecurity.org). Trains, the classic means of public transportation in British India, diminished in importance during the last decade of the 20th century. There are 8,163 kilometers of railway tracks. Pakistan Railways, an autonomous agency under the Ministry of Railways, operates the railroad system. Over the past 15 years, there has been a marked shift in freight traffic from rail to highways, a trend that the government hopes to stabilize and reverse. Railways carry about 15 percent of freight traffic and road vehicles 85 percent. The rail system comprises 781 stations. Rolling stock includes about 550 locomotives, 4,250 passenger coaches, and 32,000 freight cars. Pakistan Railways plans to improve railroad's share of long-haul freight traffic, upgrade track to permit trains to operate at higher speeds, and rehabilitate infrastructure to make better use of capacity (NationalEncyclopedia).

Pakistan's infrastructure is poor and suffers from decades of neglect. Roads and railways are insufficient and in poor condition. Both the telephone system and the provision of electricity are hampered by corrupt and inefficient governmental service providers, which increasingly face competition from private entrepreneurs (NationalEncyclopedia). It is impossible to be a global power if such a large portion of your nation is left without running water, gas, or electricity for periods of time. These can be considered basic necessities in today's world, allowing people to freely move about and not focus on basic survival. When a person no longer has daily issues regarding basic needs, they can spend their time fixing other problems and creating wealth for themselves and their country.

\section{Results and Conclusion}

Through the study of Pakistan's history, it is clear that they are a country that is not yet unified. Government ineptitude, systemic problems such as infrastructure, extremist violence, and foreign relations have hampered Pakistan's ability to become an emerging power. While other countries in the area like India have 
slowly embraced change to join the new world economy, Pakistan has lagged behind due to bickering in the government and lack of cohesion between the people.

This country has yet to find that leader that will unify them and truly make them a nation. This will be no easy task, but it is crucial that the people of Pakistan find a way to work together. They are in a very unstable area of the world, with constant pressure and influence from foreign governments to act one way or another. Until Pakistan is able to make its own decisions for the good of its own people, their current troubles will not easily go away.

It is crucial that they find a way to improve their failing infrastructure to entice greater foreign investment, as they are truly lagging in this department. They must also find a way to handle the constant conflicts in the Middle East in a savvy way that doesn't upset their allies but also doesn't put them at unnecessary risk. Until Pakistan finds a leader to bring these changes, they will always be behind the proverbial eight ball. Without vision and direction, they will always remain a divided country with failed potential.

\section{References}

http://www.digital-development-debates.org/issue-07-transition--state--the-rise-of-religious-extremism-in-pakistan.html http://www.bbc.com/news/world-south-asia-12966786

http://www.bbc.co.uk/history/british/modern/partition1947_01.shtml

http://www.pakistananalysis.com/en/analysis/international/item/240-religious-extremism-in-pakistan-a-rude-awakening.html http://www.satp.org/satporgtp/countries/pakistan/database/casualties.htm

http://america.aljazeera.com/opinions/2015/1/pakistan-counterterrorismtalibanabdulaziznawazsharif.html

http://www.nytimes.com/2014/12/17/world/asia/taliban-attack-pakistani-school.html

http://foreignpolicy.com/2015/01/26/the-art-of-u-s-pakistan-relations/

https://foreignpolicy.com/2015/04/01/the-dangerous-delicate-saudi-pakistan-alliance-yemen-iran/

http://www.globalsecurity.org/military/world/pakistan/infras.html

http://www.nationsencyclopedia.com/economies/Asia-and-the-Pacific/Pakistan.html

2013 Education in Pakistan: State of affairs at a glance by Syed Wajahat Ali and Fatima Siddiqui. 